\title{
STUDI KUALITAS AIR SECARA FISIKA DAN KIMIA SUNGAI ANCAR - KOTA MATARAM
}

\author{
Ida Bagus Rai Wiadnya ${ }^{1 \bowtie}$, Gunarti $^{2}$, Sri Witanti Dinasia ${ }^{3}$ \\ ${ }^{1}$ Jurusan Analis Kesehatan, Poltekkes Kemenkes Mataram, Indonesia \\ ${ }^{2}$ Balai Pengujian Dinas Kimpraswil Prov. NTB
}

Genesis Naskah:

\begin{abstract}
Abstrak
Air sungai Ancar merupakan sungai yang melalui daerah yang berpenduduk padat dan digunakan juga untuk pertanian, pembuangan limbah rumah tangga, sampah dan limbah Industri rumah tangga ( tahu dan tempe ) serta berbagai bentuk aktivitas penduduk dilakukan di sana seperti mandi, cuci, kakus dan lain-lain. Penelitian ini bertujuan untuk mengetahui kualitas air secara fisik dan kimia sungai Ancar - Kota Mataram. Penelitian ini merupakan penelitian deskriptif yaitu, penelitian yang bertujuan untuk mendalami masalah yang telah ada secara luas, penelitian ini untuk menemukan keterangan mengenai segala sesuatu yang relevan dengan masalah yang diteliti, yakni teori yang dipakai, pendapat para ahli mengenai aspek tersebut, penyelidikan-penyelidikan yang telah dilakukan selama ini dan hasil-hasilnya yang sedang berjalan ataupun masalah-masalah yang disarankan oleh ahli-ahli. (Surakhmad, 1980). Tempat pengambilan sampel dilakukan pada 3 titik lokasi di daerah aliran sungai Ancar, yaitu : Gontoran - Bertais, Karang Bedil - Mataram Timur dan Gerisak - Tanjung Karang. Dengan parameter penelitian secara fisika; suhu, pH, Warna, dan Kekeruhan sedangkan parameter kimia meliputi: DO, BOD, Ammoniak, Nitrit, Organik Jumlah, Alkaliniti dan Asiditi. Dari hasil pengujian parameter fisika dan kimia yang diperoleh, dapat diambil suatu kesimpulan bahwa kualitas air sungai Ancar masih memenuhi ketentuan baku mutu kualitas air golongan B atau air baku menurut PP. No. 20 Th. 1990 tentang pengendalian pencemaran air dan PERMENKES. RI 416/MENKES/PER/IX/1990. Dampak pencemaran limbah pertanian akibat pemakaian pupuk umumnya, dan limbah industri rumah tangga belum menunjukkan gejala yang serius.
\end{abstract}

Kata kunci : Kualitas Air, Fisika, Kimia.

\section{TITLE WRITTEN IN ENGLISH: NEW ROMAN TIMES 11 PT CENTER BOLD MAXIMUM 12 WORDS}

\begin{abstract}
Ancar river water is a river that passes through densely populated areas and is also used for agriculture, disposal of household waste, garbage and industrial household waste (tofu and tempeh) as well as various forms of population activities carried out there such as bathing, washing, latrines and others. other. This study aims to determine the physical and chemical water quality of the Ancar River - Mataram City. This research is a descriptive research that is, research that aims to explore issues that have been widely available, this research is to find information about everything that is relevant to the problem under study, namely the theory used, expert opinions on these aspects, investigations has been done so far and the results that are running or problems suggested by experts. (Surakhmad, 1980). Samples were taken at 3 locations in the Ancar River Basin, namely: Gontoran - Bertais, Karang Bedil - East Mataram and Gerisak - Tanjung Karang. With research parameters in physics; temperature, $\mathrm{pH}$, color, and turbidity while chemical parameters include: DO, BOD, Ammonia, Nitrite,
\end{abstract}


Organic Amount, Alkalinity and Acid. From the results of testing the physical and chemical parameters obtained, it can be concluded that the quality of the Ancar river water still meets the quality standard requirements for class B or standard water quality according to PP. No. 20 th. 1990 concerning the

control ofpollution waterand the Ministry of Health. RI 416 / MENKES / PER / IX / 1990. The impact of agricultural waste pollution due to the use of fertilizers in general, and household industrial waste has not shown serious symptoms.

Keywords: Chemistry, Physics, Water Quality 


\section{Pendahuluan}

Aliran air Sungai Ancar melalui daerah yang berpenduduk padat juga digunakan untuk pertanian, pembuangan limbah rumah tangga, sampah dan limbah Industri rumah tangga (tahu dan tempe) serta berbagai bentuk aktivitas penduduk dilakukan di sana seperti mandi, cuci, kakus. Air merupakan kebutuhan mutlak bagi setiap mahluk hidup, bagi manusia air diperlukan diantaranya untuk minum, memasak, mandi, mencuci, kegiatan pertanian dan industri. Air makin mahal dan sulit diperoleh karena sumber air sudah menipis atau akibat pencemaran sehingga menyebabkan menurunnya fungsi air dari fungsi sebelumnya.

Berdasarkan survei di lapangan diketahui keadaan lingkungan di sekitar lokasi pengambilan sampel di daerah Bertais terdapat areal persawahan dan kebun - kebun, aktivitas penduduk seperti mandi, cuci, kakus juga dilakukan di lokasi tersebut, keadaan lingkungan di sekitar lokasi pengambilan sampel di daerah Karang Bedil terlihat bangunan rumah penduduk cukup padat dimana pipa-pipa buangan dari rumah - rumah tersebut mengarah ke badan sungai, di sebelah utara sungai terdapat tumpukan sampah dan di dalam sungai banyak sampah yang tertahan. Untuk keadaan lingkungan di sekitar tempat pengambilan sampel di daerah Gerisak terlihat aliran buangan limbah penduduk dialirkan ke sungai, sampah-sampah dan limbah pembuatan tempe dan tahu juga dibuang ke sungai, baik yang berupa limbah cair maupun limbah padat, di pinggiran sungai juga terdapat kandang-kandang ternak penduduk.

Berdasarkan data Biro Pusat Statistik Mataram tahun 2014, diketahui tingkat kepadatan penduduk dari ke tiga keluruhan, dimana titik lokasi tempat pengambilan sampel termasuk di dalam wilayah-wilayah Kelurahan tersebut, yaitu: Kelurahan Bertais-Gontoran dengan tingkat kepadatan penduduk sebesar
$5.482 \mathrm{Jiwa} / \mathrm{km}^{2}$, Kelurahan Mataram TimurKarang Bedil dengan tingkat kepadatan penduduk sebesar $6.449 \mathrm{Jiwa} / \mathrm{km}^{2}$ dan Kelurahan Tanjung Karang-Gerisak dengan tingkat kepadatan penduduk 3,608 Jiwa $/ \mathrm{km}^{2}$. Untuk lebih jelasnya dapat dilihat pada tabel 1 di bawah ini.

Tabel. 1 Kepadatan Penduduk per kelurahan

\begin{tabular}{|c|c|c|c|c|}
\hline No. & $\begin{array}{c}\text { Kelu } \\
\text { raha } \\
\mathrm{n}\end{array}$ & $\begin{array}{c}\text { Luas } \\
\text { Wilayah } \\
(\mathrm{km} 2)\end{array}$ & $\begin{array}{c}\text { Jumlah } \\
\text { Pendud } \\
\text { uk }\end{array}$ & $\begin{array}{c}\text { Kepadatan } \\
\text { Penduduk }\end{array}$ \\
\hline 1 & 2 & 3 & 4 & 5 \\
\hline 1 & $\begin{array}{l}\text { Bert } \\
\text { ais }\end{array}$ & 2,04 & 11.183 & 5.482 \\
\hline 2 & $\begin{array}{l}\text { Mata } \\
\text { ram } \\
\text { Tim } \\
\text { ur }\end{array}$ & 2,27 & 14.639 & 6.449 \\
\hline 3 & $\begin{array}{l}\text { Tanj } \\
\text { ung } \\
\text { Kara } \\
\text { ng }\end{array}$ & 4,60 & 16.598 & 3.608 \\
\hline
\end{tabular}

Sumber : Biro Pusat Statistik - Mataram, 2014

\section{METODE PENELITIAN}

Penelitian ini merupakan penelitian deskriptif yaitu, penelitian yang bertujuan mendalami masalah yang telah ada secara luas, penelitian ini untuk menemukan keterangan mengenai segala sesuatu yang relevan dengan masalah yang diteliti, yakni teori yang dipakai, pendapat para ahli mengenai aspek tersebut, penyelidikan-penyelidikan yang telah dilakukan selama ini dan hasilhasilnya sedang berjalan ataupun masalahmasalah yang disarankan oleh ahli-ahli. (Surakhmad, 1980). 
Penentuan lokasi pengambilan sampel didasarkan atas keadaan lingkungan pada lokasi pengambilan sampel.

Teknik pengambilan sampel adalah stratified cluster sample dan diambil di tiga titik lokasi yaitu :
a). Gontoran Bertais $\left(A_{1}\right)$
b). Kr. Bedil-Mataram Timur. $\left(A_{2}\right)$
c). Gerisak - Tanjung Karang $\left(\mathrm{A}_{3}\right)$

\section{Alat, Bahan dan Pereaksi}

Alat-alat yang digunakan dalam penelitian ini adalah Penyuling, botol BOD Winkler, Bulb / filter, biuret, cuvet, gelas ukur, gelas piala, kertas saring, labu ukur, labu Erlenmeyer, magnetic stirrer, Nephelometer, pipet tetes, pipet ukur, pipet volumetric, $\mathrm{pH}$ meter, penangas air, Spektrofotometer, thermometer dan tabung COD.

Bahan dan pereaksi yang digunakan dalam penelitian ini adalah air suling, Mangan Sulfat, Alkali Iodida Azida, Natrium Tiosulfat $0,025 \mathrm{~N}$, Amilum 1\%, skala warna $500 \mathrm{mg} / \mathrm{L}$, baku kekeruhan $40 \mathrm{UKN}$, baku Nitrit $250 \quad \mathrm{mg} / \mathrm{L}, \quad$ Sulfanilat, Naftiletilendiamin Dihidroklorida, Asam Sulfat pekat, baku Amonium $1000 \mathrm{mg} / \mathrm{L}$, larutan Nessler, buffer $\mathrm{pH} 4$, buffer $\mathrm{pH} 7$, $\mathrm{NaOH} 6 \mathrm{~N}, \mathrm{NaOH} 1 \mathrm{~N}, \mathrm{NaOH}$ 0,02 N, Asam Sulfat $1 \mathrm{~N}$, Asam Sulfat 0,1 N, Asam Sulfat 0,02 N, Kalium Bikromat, Mercury Sulfat, Perak Sulfat, Ferro Amonium Sulfat, Asam Sulfat $8 \mathrm{~N}$ bebas Zat Organik, Asam Oxalat $0,01 \mathrm{~N}$, Kalium Permanganat 0,01 N, (Alaerts dan Santika, 1987)

\section{Prosedur Kerja}

\section{Uji Suhu}
a. Termometer di kalibrasi dengan thermometer baku sebaiknya dilakukan secara berkala.
b.Dilakukan pemeriksaan suhu di daerah lokasi dengan cara menempatkan

thermometer sedemikian rupa sehingga tidak kontak langsung dengan cahaya matahari biasanya dilindungi dengan bayangan badan, tunggu sampai skala suhu pada thermometer menunjukkan angka yang stabil, kemudian catat suhu udara.

c. Termometer langsung diselupkan ke dalam air sampai batas skala baca, biarkan 2-5 menit sampai skala suhu pada thermometer menunjukkan angka yang stabil, pembacaan skala thermometer harus dilakukan tanpa mengangkat lebih dahulu thermometer dari air, (Departemen PU,1986).

\section{Uji pH}

1. Kalibrasi alat, (Departemen PU,1986)

a. Perhatikan petunjuk pemakaian alat dari pabrik

b. Bilas elektroda dengan larutan penyangga $\mathrm{pH} 7$ sebanyak tiga kali, kemudian keringkan dengan kertas tissue, ukur $\mathrm{pH}$ larutan buffer dan atur alat sehingga skala $\mathrm{pH}$ menunjukkan angka yang sesuai dengan $\mathrm{pH}$ larutan buffer.

c. Bilas elektroda dengan larutan penyengga $\mathrm{pH} 4$ sebanyak tiga kali, kemudian keringkan dengan kertas tissue, ukur $\mathrm{pH}$ larutan buffer dan atur alat sehingga skala $\mathrm{pH}$ menunjukkan angka yang sesuai dengan $\mathrm{pH}$ buffer.

2. Penentuan pH, (Departemen PU,1986).

a. Bilas elektroda dengan air suling sebanyak tiga kali dan keringkan dengan kertas tissue.

b. Rendamlah eletroda ke dalam contoh selama \pm 1 menit kemudian keringkan dengan kertas tissue.

c. Ganti contoh dan rendamlah elektroda ke dalam contoh tersebut sampai $\mathrm{pH}$ meter menunjukkan pembacaan yang tetap. 


\section{Uji Oksigen Terlarut (DO)}

Metode : Titrimetri Iodometri, (Depkes,1990)

a. Tambahkan $1 \mathrm{ml}$ larutan $\mathrm{MnSO}_{4}$ dan 1 ml larutan Alkali Iodida Azida berturut-turut ke dalam botol BOD yang berisi contoh.

b. Tutup botol BOD dengan hati-hati kemudian kocok dengan membolakbalikan botol beberapa kali, biarkan mengendap.

c. Buka tutup botol BOD dan tambahkan $1 \mathrm{ml} \mathrm{H}_{2} \mathrm{SO}_{4}$ pekat melalui dinding dalam botol, kemudian botol segera ditutup kembali.

d. Kocok dengan cara membolakbalikkan botol sampai semua endapan melarut.

e. Diamkan selama 5-10 menit

f. Ukur $200 \mathrm{ml}$ larutan dan masukkan ke dalam labu Erlenmeyer titrasi dengan larutan baku Natrium Tiosulfat $0,025 \mathrm{~N}$ sampai terjadi warna kuning muda.

g. Tambahkan indikator amilum 1\% 1-2 ml sampai timbul warna biru dan titrasi dilanjutkan hingga warna biru hilang pertama kali.

h. Catat seluruh pemakaian larutan Natrium tiosulfat. Apabila perbedaan pemakaian larutan natrium tiosulfat secara duplo lebih dari $0,10 \mathrm{ml}$ ulangi pengujian, apabila kurang dari $0,01 \mathrm{ml}$ rata-ratakan hasilnya untuk perhitungan oksigen terlarut.

\section{Uji Warna}

Metode : Spektrofotometri, (Departemen PU,1986).

a. Buat kurva kalibrasi dengan membaca larutan baku dengan skala warna 2,0 5,0 ,10,0 dan 25,0 mg/L PtCo dengan spektrofotometer pada panjang gelombang $355 \mathrm{~nm}$.

b. Contoh uji terlebih dahulu di saring dengan kertas saring berpori 0,45 um, kemudian dibaca serapan-masuknya seperti pada larutan baku di atas, nilai warna contoh uji akan terbaca pada display spektrofotometer.

\section{Uji Kekeruhan}

Metode : Nephelometri, (Departemen PU,1986).

a. Kalibrasi Nephelometer dilakukan dengan mengikuti petunjuk Peng-gunaan alat yang dikeluarkan oleh pabriknya.

b. Pemeriksaan kekeruhan lebih rendah dari 40 UKN, dilakukan dengan mengocok dan membiarkan hingga gelembung udara hilang, kemudian masukkan ke dalam tabung pada Nephelometer. Baca skala kekeruhan secara langsung dari alat, hitung kekeruhan dari kurva kalibrasi.

c. Pemeriksaan contoh yang mempunyai kekeruhan lebih tinggi dari 40 UKN maka harus dilakukan pengenceran. Sehingga di peroleh skala kekeruhan antara $30-40$ UKN.

\section{Uji Nitrit}

Metode : Brusin Sulfat, (Depkes,1990)

a. Optimalkan alat spektrofotometer sesuai petunjuk penggunaan alat.

b. Pipet $50 \mathrm{ml}$ masing-masing larutan standar Nitrit dan contoh air, kemudian masukkan ke dalam labu Erlenmeyer.

c. Tambahkan $1 \mathrm{ml}$ larutan asam sulfanilat.

d. Biarkan larutan tersebut bereaksi selama 2-8 menit.

e. Tambah $1 \mathrm{ml}$ larutan naftil etilendiamin dihidroklorida, aduk dan biarkan paling sedikit 10 menit, tetapi tidak lebih dari 2 jam.

f. Masukkan ke dalam cuvet pada alat spektrofotometer dengan panjang gelombang $543 \mathrm{~nm}$, baca serapan masuknya.

g. Perhitungan :

1) Kadar Nitrit di cari dengan menggunakan kurva kalibrasi.

2) Apabila kadar Nitrit $>0,5 \mathrm{mg} / \mathrm{L}$ ulangi pengujian dengan cara mengencerkan contoh uji.

\section{Uji Amoniak}

Metode : Nessler, (Depkes,1990). 
a. Tahap Penyulingan Contoh Uji.

1. Ukur $300 \mathrm{ml}$ contoh, masukkan ke dalam labu penyuling $500 \mathrm{ml}$.

2. Tambahkan $25 \mathrm{ml}$ larutan penyangga borat serta beberapa butir batu didih.

3. Tepatkan $\mathrm{pH}$ menjadi 9,5 dengan penambahan larutan $\mathrm{NaOH}, 6 \mathrm{~N}$ menggunakan $\mathrm{pH}$ meter.

4.Hidupkan alat penyuling dan atur kecepatan penyulingan 6-10 ml/menit.

5.Tampung air sulingan ke dalam labu Erlenmeyer $250 \mathrm{ml}$ yang telah di isi 30 ml larutan asam borat dan tampung air suling sebanyak $120 \mathrm{ml}$ atau sampai tidak mengandung ammonia yang dapat diketahui dengan kertas lakmus.

6.Encerkan menjadi $300 \mathrm{ml}$ dengan penambahan air suling.

7. Contoh uji siap untuk di uji.

b. Pengujian Kadar Amonium, (Depkes,1990)

1. Ukur $50 \mathrm{ml}$ masing-masing larutan baku Amonium dan contoh uji, masukkan ke dalam labu Erlenmeyer.

2. Tambahkan $1 \mathrm{ml}$ larutan Nessler, kocok dan biarkan proses reaksi berlangsung paling sedikit 10 menit.

3. Masukkan ke dalam cuvet pada alat spektrofotometer dengan panjang gelombang $410 \mathrm{~nm}$, baca serapanmasuknya.

4. Perhitungan :

Kadar Amonium di cari dengan menggunakan kurva kalibrasi.

Apabila kadar Amonium > $5 \mathrm{mg} / \mathrm{L}$, ulangi pengujian dengan cara mengencerkan contoh uji.

\section{Uji BOD}

Metode : Titrimetrik, (Depkes,1990)

Sama dengan cara kerja pada pengujian Oksigen terlarut.

Keterangan :

$\mathrm{DO}_{0}: \mathrm{mg} / \mathrm{L}$ Oksigen terlarut sebelum terjadi proses perombakan.
$\mathrm{DO}_{5}: \mathrm{mg} / \mathrm{L}$ Oksigen terlarut sesudah terjadi proses perombakan.

\section{Uji Zat Organik Jumlah ( Angka Permanganat )}

Metode : Permanganometri (Depkes,1990).

a. Kocok dan ukur $100 \mathrm{ml}$ contoh uji ke dalam labu Erlenmeyer $300 \mathrm{ml}$.

b. Tambahkan larutan baku kalium permanganat beberapa tetes ke dalam contoh uji hingga terjadi warna merah muda.

c. Masukkan 3 butir batu didih.

d. Panaskan hingga mendidih selama 1 menit.

e. Tambahkan $10 \mathrm{ml}$ larutan baku kalium permanganat $0,01 \mathrm{~N}$.

f. Panaskan hingga mendidih selama 10 menit.

g. Tambahkan $10 \mathrm{ml}$ larutan baku asam oxalat $0,01 \mathrm{~N}$.

h. Titrasi dengan larutan kalium permanganat hingga warna merah muda.

i. Catat pemakaian larutan baku kalium permanganat.

j. Apabila pemakaian larutan baku kalium permanganat $>7 \mathrm{ml}$, ulangi pengujian dengan cara mengencerkan contoh uji.

\section{Uji Aciditas (Keasaman)}

Metode : Potensiometri, (Departemen PU,1986).

a. Ukur $100 \mathrm{ml}$ contoh uji dan masukkan ke dalam labu Erlenmeyer $300 \mathrm{ml}$.

b. Celupkan elektroda ke dalam contoh uji, baca dan catat $\mathrm{pH}$ contoh uji.

c. Apabila pH contoh uji di bawah 3,7 titrasi contoh uji dengan larutan baku $\mathrm{NaOH} 0,02 \mathrm{~N}$ sampai $\mathrm{pH} 3,7$ dan catat pemakaian $\mathrm{NaOH}$ (A') yang digunakan.

d. Apabila pH contoh uji 3,7 titrasi contoh uji dengan larutan baku $\mathrm{NaOH} 0,02 \mathrm{~N}$ sampai $\mathrm{pH} 8,3$ dan catat pemakaian larutan $\mathrm{NaOH}$ (A").

e. Jumlahkan pemakaian $\mathrm{NaOH}$ (A) yang diperlukan untuk perhitungan keasaman total dari data 1) dan 2). 
f. Apabila perbedaan pemakaian $\mathrm{NaOH}$ dalam titrasi secara duplo $>0,1 \mathrm{ml}$ ulangi pengujian, apabila kurang atau sama dengan $0,1 \mathrm{ml}$ rata-ratakan hasilnya.

\section{Uji Alkalinitas (Kebasaan)}

Metode : Potensiometri, (Departemen PU,1986)

a. Ukur $100 \mathrm{ml}$ contoh uji masukkan ke dalam labu erlenmeyer $300 \mathrm{ml}$.

b. Celupkan eletroda $\mathrm{pH}$ meter ke dalam contoh uji.

c. Titrasi contoh uji dengan larutan baku asam sulfat $0,02 \mathrm{~N}$ sampai $\mathrm{pH} 4,9$.

d. Cata pemakaian larutan asam untuk perhitungan.

e. Apabila pemakaian larutan baku asam sulfat $0,02 \mathrm{~N}>3 \mathrm{ml}$ ulangi

Pengujian sebagai berikut :

a. Ukur $100 \mathrm{ml}$ contoh uji masukkan ke dalam labu Erlenmeyer.

b. Titrasi contoh uji dengan larutan baku asam sulfat $0,1 \mathrm{~N}$ sampai $\mathrm{pH} 4,6$

c. Catat pemakaian larutan asam, masukkan ke dalam perhitungan.

d. Apabila pemakaian larutan baku asam sulfat $0,1 \mathrm{~N}>3 \mathrm{ml}$ ulangi pengujian seperti langkah 5), 1) di atas dan lanjutkan titrasi sampai pH 4,3 dan catat pemakaian larutan baku asam sulfat.

e. Apabila perbedaan pemakaian larutan baku asam secara duplo $>0,01 \mathrm{ml}$ ulangi pengujian, apabila kurang atau sama dengan $0,1 \mathrm{ml}$ rata-ratakan hasilnya untuk perhitungan.

\section{HASIL PENELITIAN}

\section{Parameter Fisika}

\section{a. Suhu}

Hasil pengukuran sampel diperoleh Suhu udara di lokasi $\mathrm{A}_{1} \& \mathrm{~A}_{2}: 29{ }^{\circ} \mathrm{C}$ dan $\mathrm{A}_{3}$ : $30,6{ }^{\circ} \mathrm{C}$, jika dibandingkan dari hasil pengukuran suhu yang di peroleh untuk $\mathrm{A}_{1}: 27,5^{\circ} \mathrm{C}, \mathrm{A}_{2}: 27,2{ }^{\circ} \mathrm{C}$ dan $\mathrm{A}_{3}: 28,6$ ${ }^{\circ} \mathrm{C}$.

b. Warna

Hasil pengukuran sampel diperoleh $\mathrm{A}_{1}$ : 4,8; $\mathrm{A}_{2}: 5,7$ dan $\mathrm{A}_{3}: 4,0$ skala PtCo.

b. Kekeruhan :

Jika di lihat dari hasil pengujian sampel nilai kekeruhan untuk sampel $A_{1}: 8,37$; $\mathrm{A}_{2}: 15,5$ dan $\mathrm{A}_{3}: 16$ skala NTU

c. $\mathrm{pH}$

Dari hasil pengujian masing-masing sampel diperoleh nilai $\mathrm{pH} \quad \mathrm{A}_{1}: 7,6 ; \mathrm{A}_{2}$ : 7,3 dan $\mathrm{A}_{3}: 7,4$

\section{Parameter Kimia}

a. Nitrit - N

Nilai nitrit sampel $A_{1} \& A_{2}: 0,02 \mathrm{ppm}$ dan $A_{3}: 0,03$ ppm

b. Amoniak

c.

hasil pengujian sampel nilai ammonium untuk sampel $\mathrm{A}_{1}: 0,10 ; \mathrm{A}_{2}$ $\& \mathrm{~A}_{3}: 0,20 \mathrm{mg} / \mathrm{L}$

d. Oksigen Terlarut

Nilai oksigen terlarut untuk sampel $A_{1}$ : 7,$2 ; \mathrm{A}_{2}: 5,8 ;$ dan $\mathrm{A}_{3}: 4,8 \mathrm{mg} / \mathrm{L}$

e. BOD

Nilai BOD untuk sampel $A_{1}: 2,6 ; A_{2}$ : 3,2 dan $\mathrm{A}_{3}: 4,8 \mathrm{mg} / \mathrm{L}$

f. $\mathrm{KMnO}_{4}$ ( Zat Organik Jumlah )

Nilai Permanganat untuk sampel $\mathrm{A}_{1}: 6,9$ ; $\mathrm{A}_{2}: 8,7$ dan $\mathrm{A}_{3}: 10,3 \mathrm{mg} / \mathrm{L}$

g. Asiditas

Hasil pemeriksaan nilai sampel $A_{1}: 7,0$; $\mathrm{A}_{2}: 8,0 ;$ dan $\mathrm{A}_{3}: 9,0 \mathrm{mg} / \mathrm{L}$

h. Alkalinitas

Hasil pemeriksaan nilai alkalinitas untuk sampel $A_{1}: 145 ; A_{2}: 100$ dan $A_{3}: 100$ $\mathrm{mg} / \mathrm{L}$ 
Untuk lebih jelasnya hasil pemeriksaan parameter fisika dan parameter kimia pada sampel air Sungai Ancar dapat dilihat pada tabel rekapitulasi di bawah ini.

Tabel 2. Hasil Pemeriksaan Parameter Fisika dan Kimia air Sungai Ancar

\begin{tabular}{|c|c|c|c|c|}
\hline No & Parameter & $\begin{array}{c}\mathrm{A}_{1} \\
( \\
\text { Gontora } \\
\mathrm{n})\end{array}$ & $\begin{array}{c}\mathrm{A}_{2} \\
( \\
\text { Karan } \\
\mathrm{g} \\
\text { Bedil) }\end{array}$ & $\begin{array}{c}\mathrm{A}_{3} \\
( \\
\text { Gerisa } \\
\mathrm{k})\end{array}$ \\
\hline 1. & Fisika & & & \\
\hline $\begin{array}{l}\text { a. } \\
\text { b. } \\
\text { c. } \\
\text { d. }\end{array}$ & $\begin{array}{l}\text { Suhu } \\
\text { Warna } \\
\text { Kekeruha } \\
\mathrm{n} \\
\mathrm{pH}\end{array}$ & $\begin{array}{c}27,5^{\circ} \mathrm{C} \\
4,8 \\
\text { skala } \\
\text { PtCo } \\
8,37 \\
\text { skala } \\
\text { TU } \\
7,6\end{array}$ & $\begin{array}{c}27,2^{\circ} \\
\text { C } \\
5,7 \\
\text { skala } \\
\text { PtCo } \\
15 \\
\text { skala } \\
\text { NTU } \\
7,3\end{array}$ & $\begin{array}{c}28,6^{\circ} \mathrm{C} \\
4,0 \\
\text { skala } \\
\text { PtCo } \\
16 \\
\text { skala } \\
\text { NTU } \\
7,4\end{array}$ \\
\hline 2. & Kimia & & & \\
\hline $\begin{array}{l}\text { a. } \\
\text { b. } \\
\text { c. } \\
\text { d. } \\
\text { e. } \\
\text { f. } \\
\text { g. }\end{array}$ & $\begin{array}{l}\text { Nitrit } \\
\text { Ammonia } \\
\mathrm{k} \\
\mathrm{DO} \\
\mathrm{BOD} \\
\text { Angka } \\
\mathrm{KMnO}_{4} \\
\text { Asiditas } \\
\text { Alkalinita } \\
\mathrm{s}\end{array}$ & $\begin{array}{c}0,02 \\
\mathrm{ppm} \\
0,10 \\
\mathrm{ppm} \\
7,2 \mathrm{ppm} \\
2,6 \mathrm{ppm} \\
6,9 \mathrm{ppm} \\
7,0 \mathrm{ppm} \\
145 \\
\mathrm{ppm}\end{array}$ & $\begin{array}{c}0,02 \\
\text { ppm } \\
0,20 \\
\text { ppm } \\
5,8 \\
\text { ppm } \\
3,2 \\
\text { ppm } \\
8,7 \\
\text { ppm } \\
8,0 \\
\text { ppm } \\
100 \\
\text { ppm }\end{array}$ & $\begin{array}{c}0,03 \\
\text { ppm } \\
0,20 \\
\text { ppm } \\
4,8 \\
\text { ppm } \\
4,8 \\
\text { ppm } \\
10,3 \\
\text { ppm } \\
9,0 \\
\text { ppm } \\
100 \\
\text { ppm }\end{array}$ \\
\hline
\end{tabular}




\section{PEMBAHASAN}

Berdasarkan hasil pengujian parameter fisika dan kimia dari ke tiga sampel yang dilakukan terdapat beberapa hal penting yaitu :

Parameter Fisika

a. Suhu

Hasil pengukuran sampel diperoleh Suhu udara di lokasi $\mathrm{A}_{1} \& \mathrm{~A}_{2}: 29{ }^{\circ} \mathrm{C}$ dan $\mathrm{A}_{3}: 30,6{ }^{\circ} \mathrm{C}$, jika dibandingkan dari hasil pengukuran suhu yang di peroleh untuk $A_{1}: 27,5{ }^{\circ} \mathrm{C}, \mathrm{A}_{2}: 27,2{ }^{\circ} \mathrm{C}$ dan $\mathrm{A}_{3}: 28,6^{\circ} \mathrm{C}$.

Pengukuran suhu sangat penting dilakukan karena mempengaruhi kelarutan zat-zat di dalam air sehingga akan berpengaruh pada nilai $\mathrm{pH}$, DO dan sebagainya., nilainya masih memenuhi ketentuan baku mutu air golongan B menurut PP. No. 20 Th. 1990 tentang pengendalian pencemaran air dan ketentuan batas maksimum air bersih menurut PERMENKES

416/MENKES/PER/IX/1990.

b. Warna

Hasil pengukuran sampel diperoleh $\mathrm{A}_{1}: 4,8$; $\mathrm{A}_{2}: 5,7$ dan $\mathrm{A}_{3}: 4,0$ skala PtCo.

Warna air biasanya disebabkan oleh zat-zat Organik yang berasal dari tumbuh-tumbuhan atau dari tanah, derajat keasaman atau $\mathrm{pH}$ sangat besar pengaruhnya pada warna air. Perbedaan nilai warna yang diperoleh kemungkinan disebabkan oleh adanya zat-zat Organik dalam jumlah yang berbeda atau keadaan geologi aliran sungai dan nilai warna dari Nilai ini masih berada di bawah ketentuan batas maksimum air bersih menurut PERMENKES.

RI. 416/MENKES/PER/IX/1990 yaitu 50 skala PtCo, tetapi nilai warna tidak boleh terdapat dalam kriteria air golongan B menurut PP. No. 20 Th. 1990 tentang pengendalian pencemaran air. a. Kekeruhan :

Jika di lihat dari hasil pengujian sampel nilai kekeruhan untuk sampel $A_{1}: 8,37 ; A_{2}: 15,5$ dan $\mathrm{A}_{3}: 16$ skala NTU

Kekeruhan disebabkan oleh partikel-partikel tanah liat dan beberapa mineral, ukuran partikel ini berkisar antara $0,2-0,5 \mathrm{u}$, yang bila dibiarkan beberapa lama akan mengendap. nilai tersebut masih di bawah ketentuan batas maksimum air bersih menurut PERMENKES. RI 416/MENKES/PER/IX/1990 yaitu : 25 skala NTU. Nilai kekeruhan tidak boleh terdapat dalam kriteria air golongan B menurut PP. No. 20 Th. 1990 tentang pengendalian pencemaran air.

b. $\mathrm{pH}$

Dari hasil pengujian masing-masing sampel diperoleh nilai $\mathrm{pH} \quad \mathrm{A}_{1}: 7,6 ; \mathrm{A}_{2}: 7,3$ dan $\mathrm{A}_{3}$ : 7,4

Nilai $\mathrm{pH}$ yang lebih besar dari 9,2 atau lebih kecil dari 6,5 dapat menyebabkan korosifitas pada pipa-pipa air dan menyebabkan beberapa senyawa kimia berubah menjadi racun yang mengganggu kesehatan dan nilai nilai tersebut masih pada range nilai $\mathrm{pH}$ pada baku mutu kualitas air golongan B menurut PP. No. 20 Th. 1990 tentang pengendalian pencemaran air yaitu 5,0 - 9,0 dan ketentuan batas maksimum air bersih menurut PERMENKES. RI 416/MENKES /PER/IX/1990 yaitu 6,5-9,0.

2. Parameter Kimia

a. Nitrit - N

Nilai nitrit sampel $\mathrm{A}_{1} \& \mathrm{~A}_{2}: 0,02 \mathrm{ppm}$ dan $\mathrm{A}_{3}$ : $0,03 \mathrm{ppm}$

Keberadaan senyawa nitrit di dalam air dapat menyebabkan "Methahemoglobine" yang menghambat perjalanan oksigen dalam tubuh dan menyebabkan penyakit "Blue Babies". nilai yang diperoleh masih di bawah batas 
maksimal yang diperbolehkan menurut baku mutu kualitas air golongan B menurut PP. No. 20 Th. 1990 dan ketentuan batas maksimum air bersih menurut PERMENKES. RI 416/MENKES/PER/IX/1990 1,0 mg/L. (Anonim,1990)

d. Amoniak

Hasil pengujian sampel nilai ammonium untuk sampel $A_{1}: 0,10 ; A_{2} \& A_{3}: 0,20 \mathrm{mg} / \mathrm{L}$

Adanya senyawa ammonium dapat menyebabkan timbulnya bau yang sagat tajam dan menusuk hidung sehingga mempengaruhi estetika dari nilai tersebut masih berada di bawah ketentuan baku mutu kualitas air golongan B yaitu $0,5 \mathrm{mg} / \mathrm{L}$ menurut PP. No. 20 Th. 1990 tetapi nilai ammonium tidak boleh ada dalam ketentuan batas maksimum air bersih menurut PEMRMENKES. RI 416/MENKES/PER/IX/1990, (Trangna N., 1993)

\section{c. Oksigen Terlarut}

Nilai oksigen terlarut untuk sampel $\mathrm{A}_{1}: 7,2$; $\mathrm{A}_{2}: 5,8 ;$ dan $\mathrm{A}_{3}: 4,8 \mathrm{mg} / \mathrm{L}$

Nilai Oksigen terlarut di dalam air dapat digunakan sebagai salah satu indikasi adanya pencemaran bila nilai oksigen tersebut kecil. nilai yang diperoleh untuk sampel A1 masih memenuhi persyaratan baku mutu kualitas air golongan B menurut PP. No. 20 Th. 1990 tentang pengendalian pencemaran air dan untuk sampel yang lain tidak memenuhi persyaratan tersebut, (Trangna N., 1993)

a. BOD

Nilai BOD untuk sampel $A_{1}: 2,6 ; A_{2}: 3,2$ dan $\mathrm{A}_{3}: 4,8 \mathrm{mg} / \mathrm{L}$

Besarnya nilai BOD merupakan indikasi secara biologis tentang adanya pencemaran Zat Organik yang terjadi di suatu perairan, besarnya nilai parameter ini dipengaruhi oleh tingkat pencemaran yang terjadi. akan tetapi nilai BOD tidak boleh ada dalam kriteria air golongan B menurut PP. No. 20 Th. 1990 tentang pengendalian pencemaran air dan ketentuan batas maksimum air bersih menurut PERMENKES.

RI. 416/MENKES/PER/IX/1990 (Anonim,1990).

b. $\mathrm{KMnO}_{4}$ ( Zat Organik Jumlah )

Nilai Permanganat untuk sampel $A_{1}: 6,9 ; A_{2}$ : 8,7 dan $\mathrm{A}_{3}: 10,3 \mathrm{mg} / \mathrm{L}$

Nilai permanganat atau $\mathrm{mg} / \mathrm{L} \mathrm{KMnO}_{4}$ juga merupakan indikasi keberadaan Zat Organik dalam suatu perairan dan nilai $\mathrm{KMnO} 4>10$ $\mathrm{mg} / \mathrm{L}$ dapat menyebabkan bau yang tidak sedap dan menimbulkan sakit perut dan nilai sampel masih berada pada batas maksimum air bersih menurut PERMENKES.

RI 416/MENKES/PER/IX/1990 akan tetapi nilai permanganat tidak boleh ada pada kriteria air golongan B (PP. No. 20 Th. 1990 tentang pengendalian pencemaran air), (Trangna N., 1993)

c. Asiditas

Hasil pemeriksaan nilai sampel $A_{1}: 7,0 ; A_{2}$ : 8,0 ; dan $\mathrm{A}_{3}: 9,0 \mathrm{mg} / \mathrm{L}$

Asiditas dapat juga menimbulkan korosifitas terhadap pipa-pipa air dan semakin tinggi nilai asiditas sampel maka korosifitas pada pipa-pipa air akan semakin cepat terjadi, tetapi nilai asiditas tidak boleh ada dalam kriteria air golongan B menurut PP. No. 20 Th. 1990 dan ketentuan batas maksimum air bersih menurut PERMENKES.

416/MENKES/PER/IX/1990, (Trangna N., 1993)

d. Alkalinitas

Hasil pemeriksaan nilai alkalinitas untuk sampel $A_{1}: 145 ; A_{2}: 100$ dan $A_{3}: 100 \mathrm{mg} / \mathrm{L}$. Seperti halnya asiditas, alkalinitas juga dapat menyebabkan korosifitas terhadap pipa-pipa air, tetapi nilai alkalinitas tidak boleh ada dalam kriteria air golongan B menurut PP. No. 20 Th. 1990 maupun ketentuan batas maksimum air bersih menurut PERMENKES. RI. 416/MENKES/PER/IX/1990. 


\section{KESIMPULAN}

Dari hasil pengujian parameter fisika dan kimia yang diperoleh, dapat diambil suatu kesimpulan yaitu :

Dari hasil pemeriksaan parameter kimia dan fisika bahwa air Sungai Ancar masih memenuhi ketentuan baku mutu kualitas air golongan B atau air baku menurut PP. No. 20 Th. 1990 tentang pengendalian pencemaran air dan PERMENKES. RI 416/ MENKES /PER/IX/1990.

\section{Saran}

1. Pencemaran air permukaan dan air tanah yang disebabkan oleh sumber pencemaran limbah penduduk yang dapat mengganggu pemanfaatan sumber air tersebut dan menimbulkan gangguan kesehatan sehingga perlu upaya penyehatan lingkungan pemukiman dengan cara pengolahan air limbah dan perbaikan sanitasi lingkungan.

2. Dampak pencemaran limbah pertanian akibat pemakaian pupuk umumnya belum menunjukkan gejala yang serius, akan tetapi penggunaan pestisida yang berlebihan dapat mempengaruhi pemanfaatan sumber-sumber air untuk itu upaya pengendalian pencemaran air limbah pertanian akibat pemakaian pestisida adalah penggunaan jenis dan dosis pemakaian pestisida yang tepat.

3. Kelestarian sumber air ini harus di jaga agar semua kehidupan di dalamnya tidak rusak , sehingga pemanfaatannya bagi semua kegiatan manusia tidak terganggu. Pembuangan air limbah penduduk, industri dan pertanian ke dalam perairan alam, yang juga merupakan sumber air akan menimbulkan berbagai masalah sehingga tingkat dan mutu kegunaan air tersebut dapat menurun atau bahkan hilang sama sekali. Dengan demikian semua air limbah yang akan di buang ke perairan (danau, waduk, aliran sungai dan sebagainya) harus bebas dari "bahan pengotor".

\section{DAFTAR PUSTAKA}

Anonim, 1986, Jilid II Pedoman Pemeriksaan Kualitas Air. Balitbang Pengairan Departemen Pekerjaan Umum.

Anonim, 1990, SNI Bidang Pekerjaan Umum mengenai Kualitas Air. Edisi akhir. Departemen Pekerjaan Umum Jakarta.

Anonim,1990, Petunjuk Pemeriksaan Air Minum/Air Bersih. Departemen Kesehatan - Pusat Laboratorium Kesehatan Jakarta.

Anonim, 2014, Laporan Biro Pusat Statistik Mataram Tahun 2014

Anonim,1990, Peraturan Menteri Kesehatan RI No. 416 Tahun 1990, Tentang Kualitas dan Persyaratan Air.

Anonim,1990. Peraturan Pemerintah No. 20 Tahun 1990, Tentang Pengendalian Pencemaran Air.

Alaerts dan Santika, 1987. Metode Penelitian Air. Usaha Nasional. Surabaya

Surakhmad. W. , 1980. Pengantar Penelitian Ilmiah (dasar, metode dan teknik) Edisi - 7. Tarsito Bandung, Bandung

Trangna N., 1993. Aspek Kualitas Air Dalam Pemanfaatan Sumber-sumber Air. Puslitbang Pengairan. Bandung. 